\title{
Juglanin suppresses fibrosis and inflammation response caused by LPS in acute lung injury
}

\author{
ZE-WU DONG ${ }^{*}$ and YU-FANG YUAN* \\ Huai'an First People's Hospital, Nanjing Medical University, Huai'an, Jiangsu 223300, P.R. China
}

Received November 27, 2016; Accepted February 5, 2018

DOI: $10.3892 /$ ijmm.2018.3554

\begin{abstract}
Acute lung injury in children is a complication showing devastating disorders linked to fibrosis progression and inflammation response. Fibrosis and inflammation response are two markers for acute lung injury. Juglanin is a natural product mainly isolated from green walnut husks of Juglans mandshurica, which isconsidered as the functional composition among a series of compounds. It exhibited effective role in various diseases by inhibiting inflammation response. In our study, the protective effects and anti-inflammatory activity of juglanin were investigated in mice and lung cells treated by lipopolysaccharide (LPS) to reveal the possible mechanism by which juglanin attenuates acute lung injury. The mice were separated into four groups. The mouse model was established with $15 \mathrm{mg} / \mathrm{kg}$ LPS injection. Juglanin dramatically reduced the inflammation of cell infiltration. Compared to mice only treated with LPS, LPS-treated mice in the presence of juglanin developed less lung fibrosis with lower levels of $\alpha$-smooth muscle-actin $(\alpha$-SMA), collagen type I, collagen type III, and transforming growth factor- $\beta 1$ (TGF- $\beta 1$ ). Additionally, juglanin markedly downregulated inflammatory cytokine secretion and phosphorylated nuclear factor- $\kappa \mathrm{B}(\mathrm{NF}-\kappa \mathrm{B})$ expression via inhibiting IKK $\alpha / \mathrm{I} \kappa \mathrm{B} \alpha$ signaling pathway. Our results indicate that juglanin has a protective role in LPS-triggered acute lung injury via suppression of fibrosis and inflammation response by $\mathrm{NF}-\kappa \mathrm{B}$ signaling pathways inactivation. Thus, juglanin may be a potential candidate as dietary supplement for acute lung injury for children in future.
\end{abstract}

Correspondence to: Dr Ze-Wu Dong, Huai'an First People's Hospital, Nanjing Medical University, 6 Beijing Road West, Huai'an, Jiangsu 223300, P.R. China

E-mail: qlc_2@163.com; dongzewuha@foxmail.com

\section{*Contributed equally}

Key words: acute lung injury, juglanin, fibrosis, inflammation, nuclear factor- $\kappa \mathrm{B}$

\section{Introduction}

Acute lung injury (ALI) is pulmonary inflammation with severe disorders, resulting in diffuse alveolar damage, leading to hypoxemia, pulmonary edema and respiratory failure $(1,2)$. The incidence of acute lung injury in children is high worldwide (3). ALI is associated with pediatric intensive care unit admissions, causing increased pediatric intensive care unit deaths (4). Previous studies in children and adults show strong relationship between the positive fluid balance and the worse outcomes, and death is involved, in patients with respiratory failure and/or ALI $(5,6)$. Additionally, the percentage of fluid overload is linked with worse oxygenation, enhanced duration of mechanical ventilation, and upregulation of hospital length stay according to a previous study (7). Only a small number of children with acute lung injury was successfully treated to inhibit fluid overload $(8,9)$. The mortality rate in patients with ALI is high due to the slow progress in understading the molecular mechanisms regarding the disease pathogenesis, as well as the poor therapeutic strategy. Further, lipopolysaccharide (LPS) results in symptoms in animal models, closely resembling ALI in human, highlighting strategies to investigate the pathogenesis of ALI $(10,11)$. Thus, finding effective methods and exploring the molecular mechanism are necessary.

Juglanin is a natural compound belonging to flavonoids, it is extracted from crude 'Polygonum aviculare', exhibiting inhibitory activity against the inflammation response as well as cancer growth (12-14). Flavonoids are common plant secondary metabolites, well known for having several biological activities in vitro and in vivo among which we can highlight their remarkable antioxidant activity $(15,16)$. In addition, flavonoids also have interesting anti-inflammatory activities against several markers (17-19). For instance, quercetin and astragalin are two important flavonoids $(20,21)$. Quercetin has been reported to have anti-inflammatory activity in various diseases (22-24). Thus, we supposed that juglanin may be also effective for suppressing inflammatory response in acute lung injury, and potentially provide a new therapeutic strategy for acute lung injury treatment. In addition, previous data also suggested that juglanin inhibits apoptosis and inflammatory response through TLR4-modulated MAPK/nuclear factor- $\mathrm{\kappa B}$ (NF-KB) and JAK2/STAT3 signaling pathways respectively in rats with hepatitis (25). Also, juglanin could decrease the level of reactive oxygen species in senescent cells induced by 
adriamycin treatment (26). Furthermore, juglanin displayed inhibitory activities against LPS-induced cytokine production in cells of macrophage RAW 264.7, such as interleukin-1 $\beta$ (IL-1 $\beta$ ), tumor necrosis factor- $\alpha$ (TNF- $\alpha$ ), and IL-6 (27). In consideration of the valid function of juglanin in various disease treatments with little toxicity, we supposed that it may be utilized for patients of children with lung injury, which could be useful for the development of dietary supplements that alleviate lung injury for children.

In the present study, experimental mice were given LPS to induce acute lung injury with severe fibrosis and inflammation response. Then, juglanin at different concentrations were administered to mice. Following, the fibrosis and inflammation response in vivo were calculated through $\alpha$-smooth muscle-actin ( $\alpha$-SMA), collagen type I and III as well as NF- $\mathrm{BB}$-related signaling pathway to illustrate the role of juglanin in acute lung injury, supplying a new and effective treatment for children with acute lung injury in future.

\section{Materials and methods}

Animal treatment. Sixty male, 6-week-old C57BL6 mice, weight range 20-22 g, were purchased from experimental animals center of Nanjing Medical University of laboratory animal center (Nanjing, China). All the mice were carefully maintained at room temperature on a 12:12 h/light:dark cycle, $35 \%$ humidity, with free access to food and water in the cages. All animal experiments were performed to minimize animal suffering according to the Guide for the Care and Use of Laboratory Animals which was issued by the National Institutes of Health in 1996. This study was approved by the Ethics Committee on Animal Research at the Department of Pediatrics, Huai'an First People's Hospital, Nanjing Medical University, Nanjing, China. The mice were divided into 6 groups: the control group without any treatment (Con, $\mathrm{n}=10)$; LPS-treated group $(15 \mathrm{mg} / \mathrm{kg}$, LPS, $\mathrm{n}=10)$; $10 \mathrm{mg} / \mathrm{kg}$ juglanin-treated group after LPS teratment (JL, $\mathrm{n}=10) ; 20 \mathrm{mg} / \mathrm{kg}$ juglanin-treated group after LPS (JH, $\mathrm{n}=10$ ); $10 \mathrm{mg} / \mathrm{kg}$ juglanin-treated group without LPS treatment (Con-JL, $\mathrm{n}=10) ; 20 \mathrm{mg} / \mathrm{kg}$ juglanin-treated group without LPS (Con-JH, n=10). After 10 days adaptation, mice from LPS group were treated by intraperitoneal injection with $15 \mathrm{mg} / \mathrm{kg}$ body weight LPS. The control group was administered with the same volume of saline. Then, the mice were consecutively administered with different concentrations of juglanin via oral gavage for 3 weeks. Juglanin, purchased from Yuanye Biotech (Shanghai, China), was dissolved in distilled water. Then, all experimental mice were sacrificed. Eyeball blood was collected and centrifuged at $12,000 \mathrm{x} \mathrm{g}$ for $15 \mathrm{~min}$ at $4^{\circ} \mathrm{C}$ for following study, and the whole lung and liver tissues were carefully harvested on $4^{\circ} \mathrm{C}$ glacial table, and then immediately frozen in liquid $\mathrm{N}_{2}$, and stored at $-80^{\circ} \mathrm{C}$ for the following studies.

Cells culture and treatment. The human lung cell line, BEAS-2B, was purchased from American Type Culture Collection (ATCC, Rockville, MD, USA), and human liver cell line L02, was obtained from KeyGen Biotech (Nanjing, China). The cells were maintained in a monolayer culture of
95\% air and $5 \% \mathrm{CO}_{2}$ at $37^{\circ} \mathrm{C}$ in Dulbecco's modified Eagle's medium (DMEM) with 10\% fetal bovine serum (FBS), $0.012 \%$ penicillin $\mathrm{G}, 0.027 \%$ streptomycin, $0.022 \%$ sodium pyruvate and $0.26 \%$ sodium bicarbonate. Juglanin stock solution was prepared in dimethyl sulfoxide (DMSO) and diluted to the desired final concentration $(0,1.25,5,10,20,40$ and $80 \mu \mathrm{M})$ in culture medium for $24 \mathrm{~h}$ before use. The final concentration of DMSO did not exceed $0.1 \%(\mathrm{v} / \mathrm{v})$.

Cell viability analysis. The lung and liver cells were planted in 96-well plates with a density of $5 \times 10^{3}$ cells/well. Then, they were treated with different concentrations ( 0 to $80 \mu \mathrm{M})$ of juglanin for different times ranging from 0 to $72 \mathrm{~h}$ for cell viability analysis through Cell Counting kit-8 (CCK-8) (Zoman Biotechnology Co., Ltd., Beijing, China) to examine cell viability according to the instructions of the manufacturer.

Inflammatory cell counts of BALF. The samples from BALF were centrifuged at $3,000 \mathrm{rpm}$ for $10 \mathrm{~min}$ at $4^{\circ} \mathrm{C}$ to pellet the cells. Then, the cell pellets were re-suspended in phosphate-buffered saline (PBS) for the total cell number with a hemacytometer, and the cytospins were prepared for other differential cell number through Wright-Giemsa staining.

Chemical index measurement. The serum tumor necrosis factor- $\alpha$ (TNF- $\alpha)$ (cat. no. MTA00B), interleukin-1 $\beta$ (IL-1 $\beta$ ) (cat. no. MLB00C), IL-4 (cat. no. M400B), IL-18 (cat. no. 7625), IL-6 (cat. no. M600B), and IL-17 (cat. no. M1700) (R\&D Systems, Minneapolis, MN, USA) were measured according to the manufacturer's protocol using an enzyme-linked immunosorbent assay (ELISA) kit. Total serum and BAL IgE and IgA levels were determined by a mouse IgE (cat. no. DY1197; R\&D Systems) and IgA (cat. no. F00295; Lengton Biological Technology, Shanghai, China) ELISA set. For the determination of cytokine levels, blood samples from the rats were obtained after sacrifice and stored at $-80^{\circ} \mathrm{C}$ until use. Lung tissue samples were isolated from the mice immediately after sacrifice, and was snapfrozen in liquid nitrogen and stored at $-80^{\circ} \mathrm{C}$ for later analysis. Lung tissue samples were collected were homogenized, and the proteins were extracted using hypotonic buffer $(25 \mathrm{mM}$ Tris-HCl, pH 8.0, $1 \mathrm{mM}$ EDTA, $5 \mu \mathrm{g} / \mathrm{ml}$ leupeptin, $1 \mathrm{mM}$ Pefabloc SC, $50 \mu \mathrm{g} / \mathrm{ml}$ aprotinin, $5 \mu \mathrm{g} / \mathrm{ml}$ soybean trypsin inhibitor, $4 \mathrm{mM}$ benzamidine) to yield a homogenate. Then the final supernatants were obtained by centrifugation at $12,000 \mathrm{rpm}$ for $20 \mathrm{~min}$. Protein concentration was determined by BCA protein assay kit (Thermo Fisher Scientific, Waltham, MA, USA) with bovine serum albumin as a standard. Next, the pro-inflammatory cytokine levels, including TNF- $\alpha$, IL-1 $\beta$, IL-18, IL-6, IL-4 and IL-17 were measured using the commercial ELISA kits, respectively, following manufacturer's instruction.

Immunohistochemical analysis. Formalin-fixed, paraffinembedded mouse lung tissue samples were processed and then stained based on routine protocol of hematoxylin and eosin (H\&E) (28). The stained slides, sectioned at $4 \mu \mathrm{M}$, were then observed with the light microscope and the digital micrographs of slides, which were taken for analyzing. The 
Table I. Primary antibodies for western blot analysis.

\begin{tabular}{|c|c|c|}
\hline Primary antibodies & $\begin{array}{l}\text { Dilution } \\
\text { ratio }\end{array}$ & Corporation \\
\hline Rabbit anti-NF-кB & $1: 1,000$ & Abcam, ab207297 \\
\hline Rabbit anti-p-NF- $\kappa B$ & $1: 1,000$ & Abcam, ab86299 \\
\hline Rabbit anti-IкB $\alpha$ & $1: 2,000$ & Abcam, ab7212 \\
\hline Rabbit anti-IL-1 $\beta$ & $1: 1,000$ & Abcam, ab9722 \\
\hline Rabbit anti-p-IKK $\alpha$ & $1: 500$ & Abcam, ab38515 \\
\hline Rabbit anti- $\alpha-S M A$ & $1: 1,000$ & Abcam, ab5694 \\
\hline $\begin{array}{l}\text { Rabbit anti-collagen } \\
\text { type I }\end{array}$ & $1: 1,000$ & Abcam, ab34710 \\
\hline Rabbit anti-TGF- $\beta 1$ & $1: 1,000$ & $\begin{array}{l}\text { Cell Signaling Technology, } \\
\text { ab3711 }\end{array}$ \\
\hline Collagen type III & $1: 1,000$ & $\begin{array}{l}\text { Cell Signaling Technology, } \\
\text { ab7778 }\end{array}$ \\
\hline GAPDH & $1: 1,000$ & $\begin{array}{l}\text { Cell Signaling Technology, } \\
\text { ab5174 }\end{array}$ \\
\hline
\end{tabular}

NF- $\kappa \mathrm{B}$, nuclear factor- $\mathrm{B}$; IL-1 $\beta$, interleukin- $1 \beta ; \alpha$-SMA, $\alpha$-smooth muscle-actin; TGF- $\beta 1$, transforming growth factor- $\beta 1$; GAPDH, glyceraldehyde 3-phosphate dehydrogenase.

inflammation score was determined by a pathologist as mild, moderate, or severe and degree of inflammation annotated as inflammatory score from 0 to 4 (minimum, 0 ; maximum, 4 ; 0 , no injury; 1 , injury up to $25 \%$ of the field; 2 , injury up to $50 \%$ of the field; 3 , injury up to $75 \%$ of the field; and 4 , diffuse injury) was calculated as an index of the degree of lung injury for each sample described.

For periodic acid-Schiff (PAS) staining methods, the lung tissue samples were fixed in $95 \%$ alcohol for $10 \mathrm{~min}$, prior to being washed, dried, stained by $1 \%$ periodic acid for $15 \mathrm{~min}$ and then washed by chilled PBS and dried twice. The tissue samples were then stained using Schiff reagent for $1 \mathrm{~h}$, washed and dried, and stained subsequently with hematoxylin for 5 min, washed and dried. Finally, the tissue samples were observed with light microscopy. Wright-Giemsa staining was also carried out, following standard instructions. For the analysis of collagen deposition, Sirius red staining was performed by Shanghai Zhenda Biotechnology, Co., Ltd. (Sanghai, China).

For immunohistochemistry analysis, the fresh lung tissue samples were fixed in formalin for $48 \mathrm{~h}$. Then the tissue block was put into paraffin and next cut into slides for the desired thickness in a microtome, and was then fixed into a slide. After washing, the samples were prepared for blocking and incubating with antibody $\alpha$-SMA (1:200) and transforming growth factor- $\beta 1$ (TGF- $\beta 1)$ (1:200), which were diluted in $5 \%$ horse serum with chilled PBS at $4^{\circ} \mathrm{C}$ overnight. Isotype-matched IgG was used instead of primary antibody as a negative control of the staining. Sections were then incubated with diluted streptavidin-peroxidase HRP at room temperature with a staining kit, following the manufacturer's instructions. The sections were then stained with hematoxylin for $5 \mathrm{~min}$ and mounted and observed with a phase-contrast microscope.
Fluorescence imaging. Tissue samples were washed twice with PBS and fixed with 3.7\% (v/v) formaldehyde in PBS for 15 min. Cells were permeabilised for 5 min with $0.1 \%$ Triton X-100. For p-NF- $\kappa \mathrm{B}$ staining, $50 \mu \mathrm{g} / \mathrm{ml}$ mouse anti-caspase-3 (1:200) antibodies were employed followed by staining with $2 \mu \mathrm{g} / \mathrm{ml}$ Alexa Fluor 488 goat anti-mouse secondary antibodies. DAPI (Sigma-Aldrich) was used in this part of the studied. Images were acquired by confocal laser scanning via epifluorescence microscopy (Sunny Biotech Co., Ltd., Shanghai, China). After observation and obtaining the representative images, ImageJ software, focused on biological-image analysis, was used to calculate the fluorescent intensity, representing the number of positive cells (29).

Western blot assays. The lung tissue samples and lung cells were homogenized into $10 \%$ (wt/vol) hypotonic buffer $(25 \mathrm{mM}$ Tris-HCl, pH 8.0, $1 \mathrm{mM}$ EDTA, $5 \mu \mathrm{g} / \mathrm{ml}$ leupeptin, $1 \mathrm{mM}$ pefabloc SC, $50 \mu \mathrm{g} / \mathrm{ml}$ aprotinin, $5 \mu \mathrm{g} / \mathrm{ml}$ soybean trypsin inhibitor, $4 \mathrm{mM}$ benzamidine) to yield a homogenate. The final supernatants were obtained by centrifugation at $12,000 \mathrm{rpm}$ for $20 \mathrm{~min}$. Protein concentration was determined by BCA protein assay kit (Thermo Fisher Scientific) with bovine serum albumin as a standard. The total protein extract was also used for western blot assays. Equal amounts $(30 \mu \mathrm{M})$ of total protein of tissues were subjected to 10 or $12 \%$ sodium dodecyl sulfate-polyacrylamide gel electrophoresis (SDS-PAGE) followed by immunoblotting using the following primary polyclonal antibodies: rabbit anti-glyceraldehyde 3-phosphate dehydrogenase (GAPDH), IL- $1 \beta$, P-NF- $\kappa$ B, NF- $\kappa$ B, p-IKK $\alpha$, I $\kappa$ B $\alpha, \alpha$-SMA, TGF- $\beta 1$, collagen type I and collagen type III. Immunoreactive bands were visualized by ECL immunoblot detection system (Pierce Biotechnology, Inc., Rockford, IL, USA) and exposed to Kodak (Eastman Kodak Co., Rochester, NY, USA) X-ray film. Each protein expression level was defined as grey value (version 4.2b, Mac OS X, ImageJ; National Institutes of Health, Bethesda, $\mathrm{MD}, \mathrm{USA})$ and standardized to housekeeping gene (GAPDH) and expressed as a fold of control. The specific information of primary antibodies used here is listed in Table I.

RT-qPCR analysis. Total RNA from tissue samples and cultured cells was isolated through the mirVana miRNA isolation kit (Ambion, Foster City, CA, USA) based on the manufacturer's instruction. Then the cDNA was synthesized from total RNA with the TaqMan miRNA reverse transcription kit (Applied Biosystems, Foster City, CA, USA). Real-time PCR was conducted using the Applied Biosystems 7500 sequence detection system with $\mathrm{iQ}^{\mathrm{TM}}$ SYBR-Green SuperMix (Bio-Rad Laboratories, Hercules, CA, USA) containing $5 \mathrm{ng}$ cDNA and $10 \mathrm{pM}$ of each primer. The data were normalized to the geometric mean of housekeeping gene GAPDH and calculated using the $2^{-\triangle \Delta C T}$ method. Fold changes in mRNA levels of target gene relative to the endogenous GAPDH control were calculated. In brief, the cycle threshold $(\mathrm{Ct})$ values of each target gene was subtracted from $\mathrm{Ct}$ values of housekeeping gene cyclophilin ( $\Delta \mathrm{Ct}$ ). The target gene $\Delta \Delta \mathrm{Ct}$ was calculated as $\Delta \mathrm{Ct}$ of target gene minus $\Delta \mathrm{Ct}$ of control. The fold change in mRNA expression was evaluated as $2^{-\Delta \Delta C t}$. All sequences involved in this study are shown as follows: sense primers of TGF- $\beta 1,5$ '-GAA GGT GAG AGG ATG G-3' and antisense primers of TGF- $\beta 1,5$ '-AGA CCT AGA CTA GGC CAA GT-3'; sense primers of collagen 

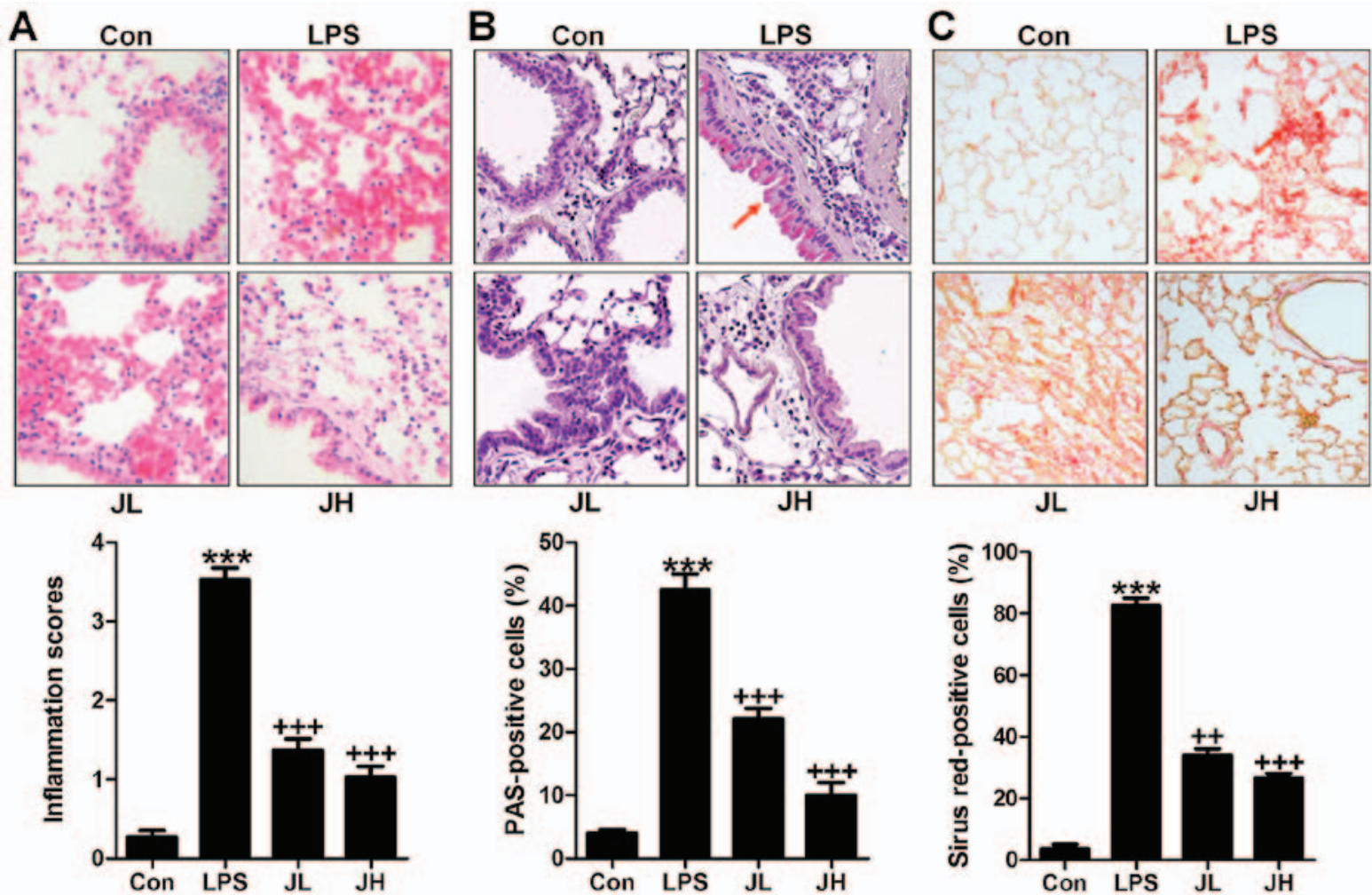

Figure 1. Lipopolysaccharide (LPS)-induced acute lung injury in mice is ameliorated for juglanin administration. (A) Upper, representative images of lung injury by hematoxylin and eosin (H\&E) staining. Lower, the quantification of inflammatory response following H\&E staining. (B) Upper, PAS staining was used to observe goblet cells in LPS-induced mice with acute lung injury. Lower, the quantification of PAS positive cells. (C) Upper, Sirius red analysis was used to calculate fibrosis levels in LPS-induced acute lung injury. Lower, the quantification of Sirius red positive cells is shown. The data are shown as mean \pm SEM $(\mathrm{n}=10) .{ }^{*} \mathrm{p}<0.05$ and ${ }^{* *} \mathrm{p}<0.001$ vs. the control (Con). ${ }^{+} \mathrm{p}<0.05,{ }^{++} \mathrm{p}<0.01$ and ${ }^{+++} \mathrm{p}<0.001$ vs. LPS-induced mice (LPS).

type I, 5'-AAA GGT AAC AAG ACG TGG-3' and antisense primers of collagen type I, 5'-TCG TAT ACT GTC AGG GAG AGA T-3'; sense primers of collagen type III 5'-GAA GGC AGA GAG AAG GTA G-3' and antisense primers of collagen type III, 5'-AGA CGG AAT GGA GAA GAC ACA T-3'; sense primers of $\alpha$-SMA, 5'-AGC TAG TGA ACA ACA GTG CG-3' and antisense primers of $\alpha$-SMA, 5'-TAA GCT CAG AGG CTA TCG TAT-3'; sense primers of GAPDH, 5'-AAT CAT AAC GCG AGG CCG GA-3' and antisense primers of GAPDH, 5'-CCA TAT ACA GTC ACC CGA CAC AC-3'.

Data analysis. Data were expressed as mean \pm standard error of the mean (SEM). Statistical analyses were performed using GraphPad Prism (version 6.0; GraphPad Software, Inc., La Jolla, CA, USA) by ANOVA with Dunnet's least significant difference post-hoc tests. A p-value $<0.05$ was considered significant.

\section{Results}

LPS-induced acute lung injury in mice is ameliorated after juglanin administration. LPS induction is well known to cause injury in different organs, including liver, renal and heart, even the lung, and has been investigated before (30). In this study, preliminary experiment was performed to verify that the inflammatory-mouse model was set up correctly through evaluating the number of macrophages, neutrophils and lymphocytes, as well as the total cells in BALF, and H\&E staining. The data indicated that after $15 \mathrm{mg} / \mathrm{kg}$ LPS treatment for $6 \mathrm{~h}$, the number of macrophages, neutrophils and lymphocytes, as well as the total BALF was significantly higher than that in the control group, which is a hallmark for ALI. In addition, H\&E staining analysis also indicated that LPS induced lung injury in mice compared to the Con group. After the preexperiments mentioned above, we considered that ALI models were successfully established (data not shown). In order to prove whether juglanin has potential value on airway inflammation in children, LPS was also involved to cause acute lung injury in mice. In this regard, H\&E staining was carried out to observe the injured condition of lung tissue samples. We found that after LPS treatment in mice, the lung tissue sample showed higher inflammation score compared to the Con group with significant difference (Fig. 1A). After, juglanin treatment, the inflammatory response was attenuated. Additionally, PAS analysis also indicated that the PAS positive cell levels were significantly increased with LPS exposure, while decreased by juglanin administration in a dose-dependent manner (Fig. 1B). Further, Sirius red assays illustrated that the fibrosis levels were more severe in LPS-treated lung tissue samples from mice. Of note, juglanin treatment indicated that the Sirius red positive cells were highly reduced ameliorating fibrosis progression (Fig. 1C). The data above suggested that LPS indeed resulted in severe lung injury, and juglanin showed protective role against acute lung injury caused by LPS in mice.

Juglanin reduces inflammatory cell infiltrate in LPS-induced mice with acute lung injury. In this regard, the role of juglanin 

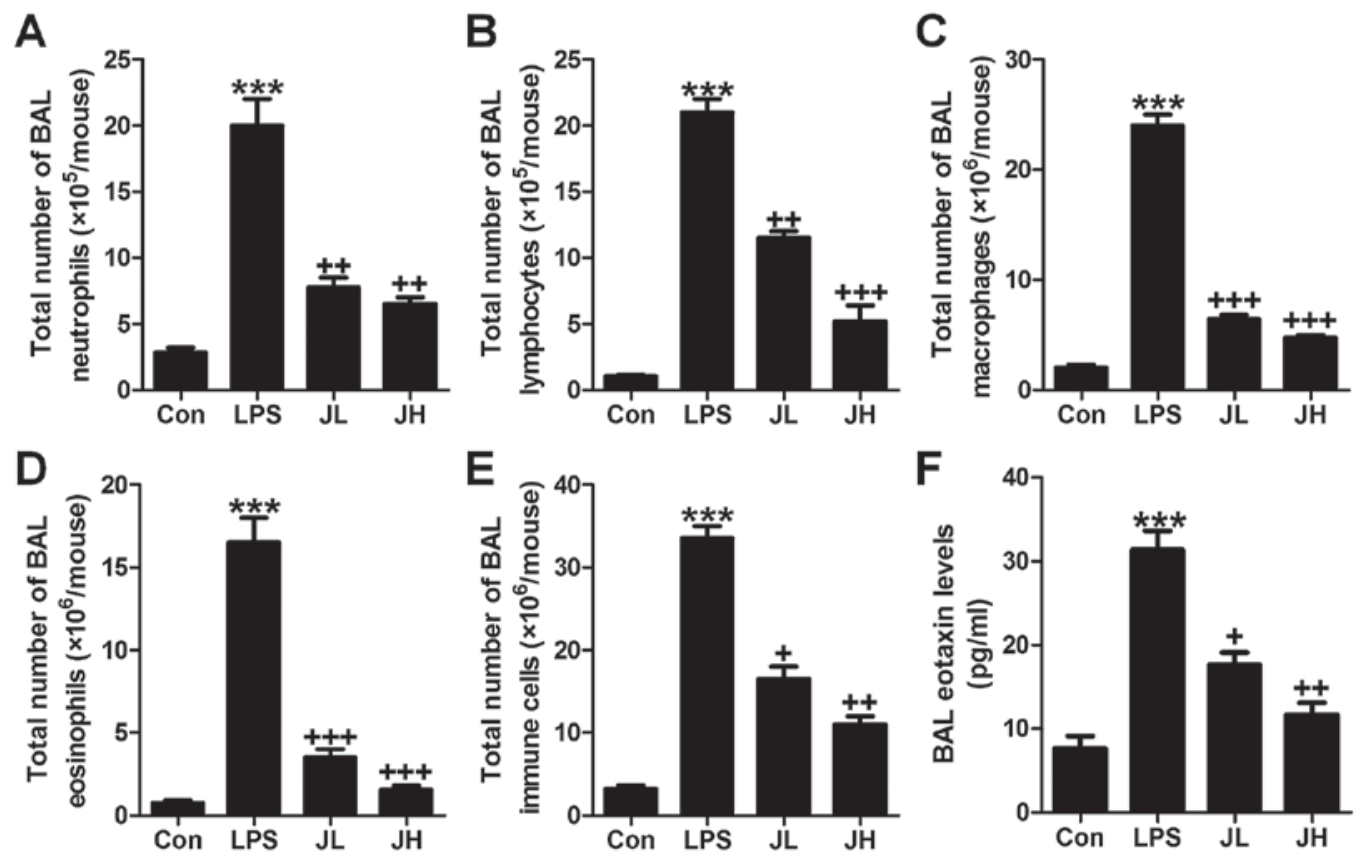

Figure 2. Juglanin reduces inflammatory cell infiltrate in lipopolysaccharide (LPS)-induced mice with acute lung injury. The number of cells in inflammation infiltration was determined. (A) Total neutrophils, (B) total lymphocytes, (C) total macrophages, (D) total eosinolhils and (E) total cells. (F) Eotaxin levels in bronchoalveolar lavages (BAL) were measured. The data are shown as mean $\pm \operatorname{SEM}(\mathrm{n}=10) .{ }^{*} \mathrm{p}<0.05$ and ${ }^{* *} \mathrm{p}<0.001 \mathrm{vs}$. the control $(\mathrm{Con}) ;{ }^{+} \mathrm{p}<0.05,{ }^{++} \mathrm{p}<0.01$ and ${ }^{+++} \mathrm{p}<0.001$ vs. LPS-induced mice (LPS)
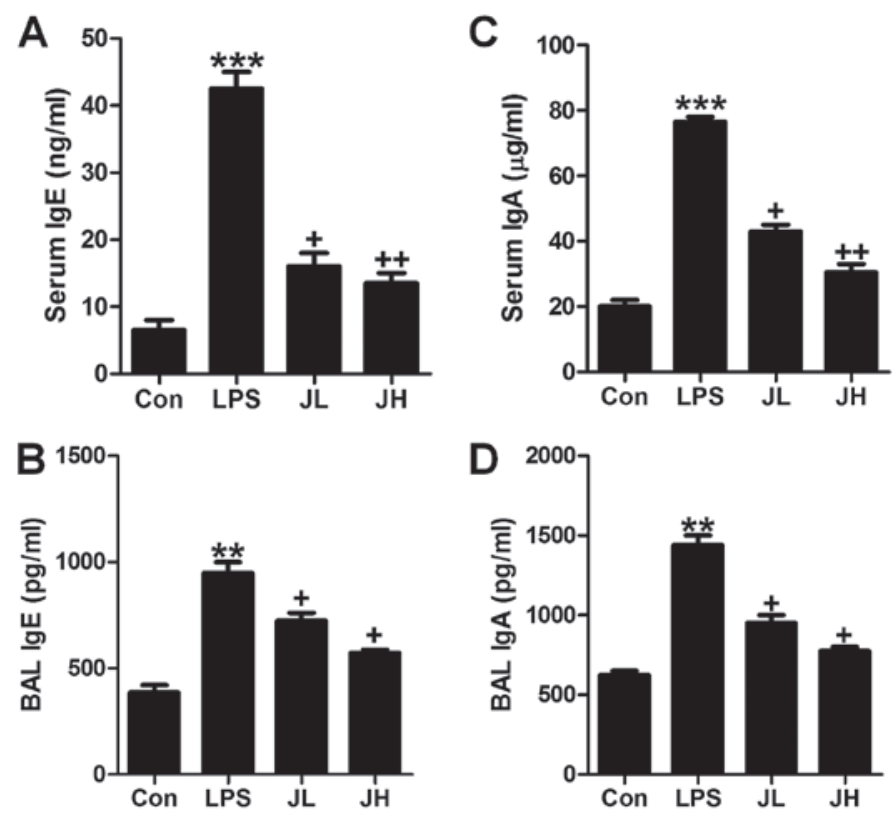

Figure 3. Juglanin downregulates $\lg E$ and $\lg \mathrm{A}$ in serum and bronchoalveolar lavages (BAL) in lipopolysaccharide (LPS)-induced mice. (A) Serum $\operatorname{lgE}$ and (B) BAL $\operatorname{lgE}$ levels were calculated in juglanin-treated mice after LPS induction. (C) Serum $\lg$ A and (D) BAL $\lg A$ levels were measured in juglanin-treated mice after LPS induction. The data are shown as mean \pm SEM $(n=10) .{ }^{*} p<0.05$ and ${ }^{* *} p<0.001$ vs. the control (Con); ${ }^{+} p<0.05,{ }^{++} p<0.01$ and ${ }^{+++} p<0.001$ vs. LPS-induced mice (LPS).

in inflammation regulation was explored. First of all, the bronchoalveolar lavage (BAL) was conducted and investigated. As shown in Fig. 2, LPS treatment contributed to acceleration of neutrophils (Fig. 2A), lymphocytes (Fig. 2B), macrophages (Fig. 2C), and eosinophils (Fig. 2D), and elevation of the total number of BAL eventually (Fig. 2E). Juglanin significantly reduced the total number of neutrophils (Fig. 2A), lymphocytes (Fig. 2B), macrophages (Fig. 2C), and eosino- phils (Fig. 2D), as well as the total number of immune cells in BAL (Fig. 2E). The whole process was in a dose-dependent manner. Furthermore, in the lung tissue samples after LPS induction, eotaxin level in BAL was apparently downregulated, which was attenuated by juglanin treatment (Fig. 2F). In conclusion, the data above indicated that juglanin has a potential role in controlling inflammation and cell infiltration in mice with acute lung injury induced by LPS. 


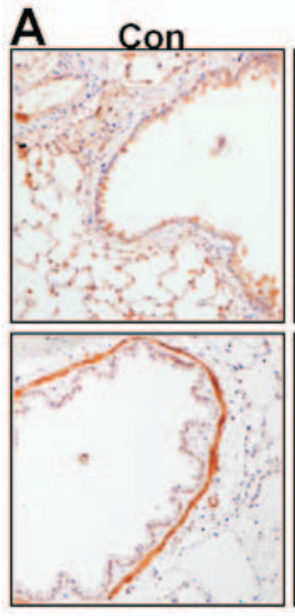

B

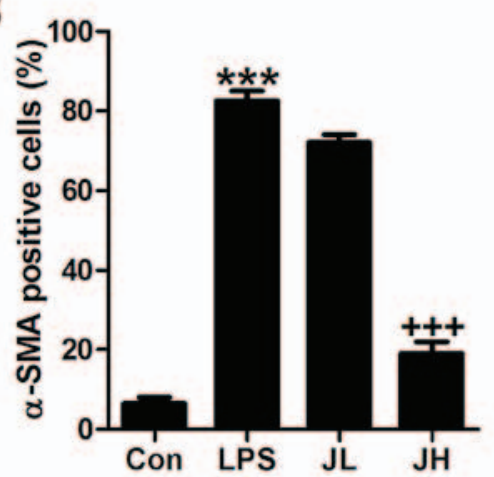

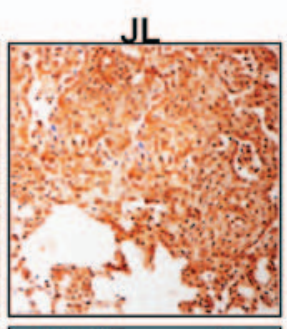
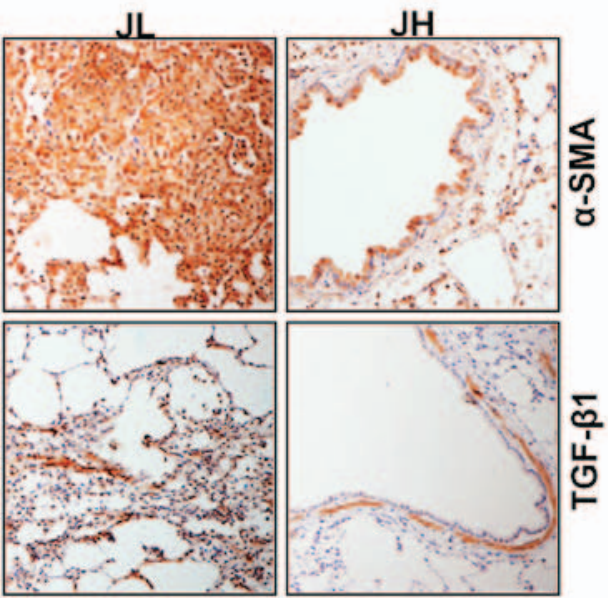

C

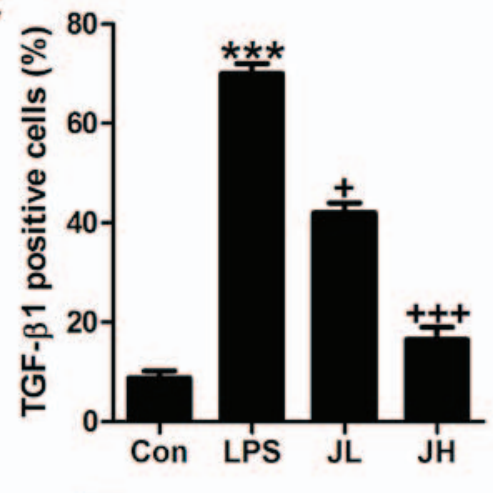

$\mathrm{JL}$ 口 JH

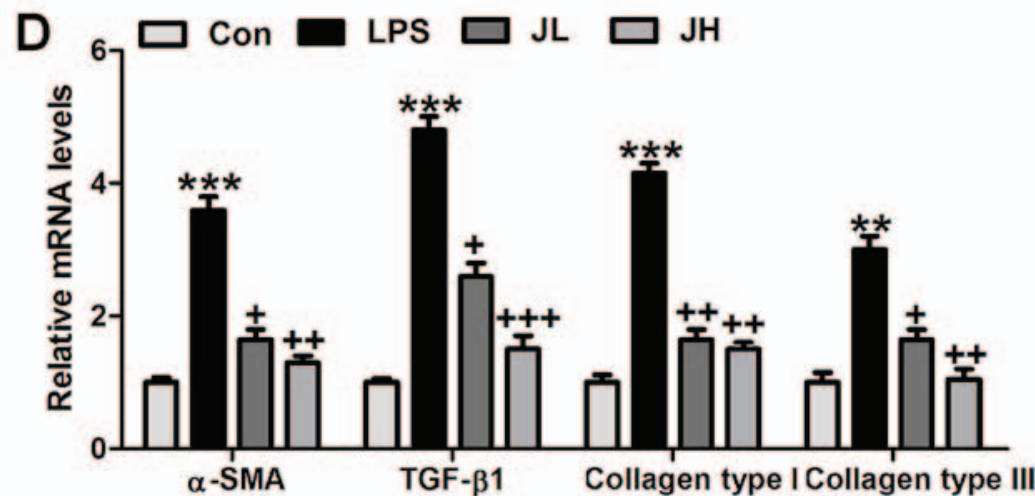

Figure 4. Juglanin-ameliorated fibrosis progression in mice induced by lipopolysaccharide (LPS). (A) Immnohistochemical analysis of fibrosis markers of $\alpha$-smooth muscle-actin ( $\alpha$-SMA) and transforming growth factor- $\beta 1$ (TGF- $\beta 1$ ). The quantification of (B) $\alpha$-SMA, and (C) TGF- $\beta 1$ was exhibited following immunohistochemical analysis. $n=6$. (D) RT-qPCR assays were conducted to explore mRNA levels of $\alpha$-SMA, TGF- $\beta 1$, collagen type I and collagen type III. The data are shown as mean \pm SEM $(\mathrm{n}=10)$. ${ }^{*} \mathrm{p}<0.05$ and ${ }^{* *} \mathrm{p}<0.001$ vs. the control (Con); ${ }^{+} \mathrm{p}<0.05,{ }^{++} \mathrm{p}<0.01$ and ${ }^{+++} \mathrm{p}<0.001$ vs. LPS-induced mice $(\mathrm{LPS})$.

Juglanin downregulates $\lg E$ and $\lg A$ in serum and $B A L$ in $L P S$-induced mice. In order to further investigate if juglanin could ameliorate LPS-induced acute lung injury, $\operatorname{lgE}$ and $\lg$ A levels in serum and BAL were calculated. Accroding to a previous study, $\operatorname{lgE}$ and $\lg \mathrm{A}$ high expression were markers contributing to various diseases (31). As shown in Fig. 3A and B, the lgE levels in serum and BAL were significantly upregulated in LPS-treatment. Juglanin administration reversed $\operatorname{lgE}$ expression levels in a dose-dependent manner. Consistent with $\operatorname{lgE}$ alteration, $\lg$ A levels in serum and BAL were also found to be highly expressed for LPS-induction, and were inhibited in serum and BAL (Fig. 3C and D). The results above indicated that juglanin has a role in suppressing $\lg \mathrm{E}$ and $\lg$ A expression levels to improve acute lung injury induced by LPS in mice.
Juglanin-ameliorated fibrosis progression in mice induced by $L P S$. Lung fibrosis is known as a significant injury induced by LPS (32). In our study, to estimate the extent of fibrosis, we calculated $\alpha$-SMA, TGF- $\beta 1$, collagen type I and collagen type III through different analysis. As shown in Fig. 4A, $\alpha$-SMA and TGF- $\beta 1$ were significantly upregulated in LPS treatment in line with previous studies (33). Of note, juglanin administration significantly downregulated $\alpha$-SMA and TGF- $\beta 1$ levels in LPS-treated mice through immunohistochemical analysis (Fig. 4B and C). IgG-isotype control staining showed no positive signal by immunohistochemical analysis. Similarly, $\alpha-$ SMA and TGF- $\beta 1$ mRNA levels, as well as collagen type I and collagen type III gene levels were also upregulated with significant difference compared to the Con ones after LPS treatment. Interestingly, juglanin at two 
Serum
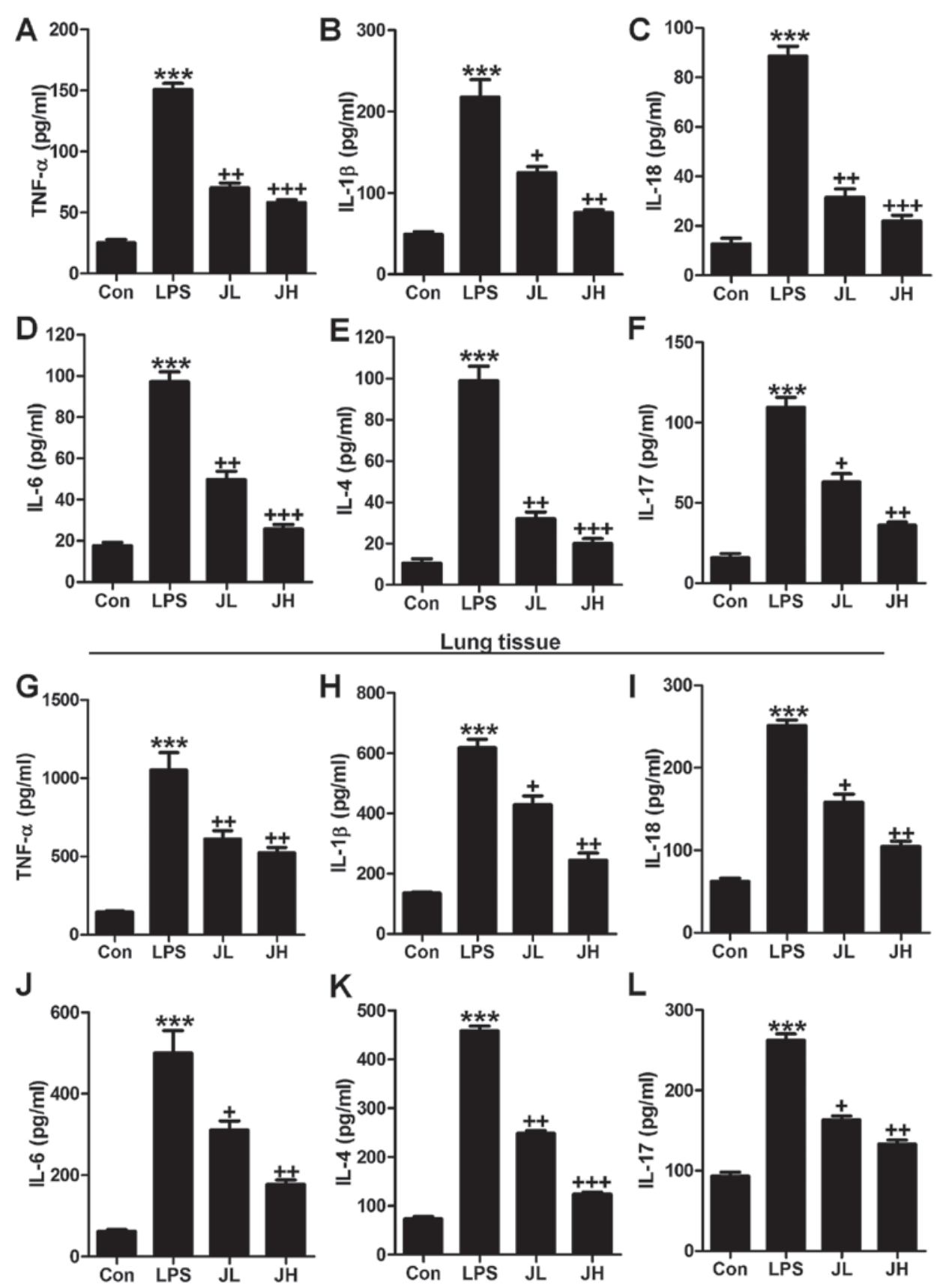

Figure 5. Juglanin improves pro-inflammatory cytokine releases caused by lipopolysaccharide (LPS). Serum pro-inflammatory cytokines were measured,

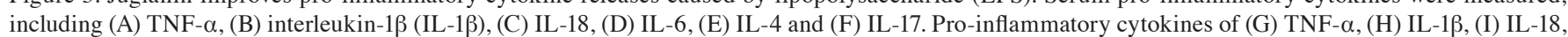
(J) IL-6, (K) IL-4 and (L) IL-17 in lung tissue samples induced by LPS were measured after juglanin administration. The data are shown as mean \pm SEM $(\mathrm{n}=10) .{ }^{*} \mathrm{p}<0.05$ and ${ }^{* *} \mathrm{p}<0.001$ vs. the control (Con); ${ }^{+} \mathrm{p}<0.05,{ }^{++} \mathrm{p}<0.01$ and ${ }^{+++} \mathrm{p}<0.001$ vs. LPS-induced mice (LPS).

concentrations reduced $\alpha$-SMA and TGF- $\beta 1$, collagen type I and III apparently compared to the LPS alone-treated group through RT-qPCR analysis (Fig. 4D). Taken together, the results in this part indicated that fibrosis was induced in mice in LPS exposure, and juglanin exhibited suppressive role in fibrosis progression in acute lung injury in mice after LPS induction.

Juglanin improves pro-inflammatory cytokine release caused by LPS. Inflammation response is known as a major reason to cause tissue injury in different organs after LPS treatment, such as liver and renal injury (34). Also, previous studies reported that LPS induction resulted in lung injury, which was also attributed to inflammatory response (35). As further confirmation, serum and lung tissue samples of pro-inflammatory cytokines of TNF- $\alpha$, IL-1 $\beta$, IL-18, IL-6, IL-4 and IL-17 were determined. As shown in Fig. 5, we found that pro-inflammatory cytokines of TNF- $\alpha$ (Fig. 5A), IL-1 $\beta$ (Fig. 5B), IL-18 (Fig. 5C), IL-6 (Fig. 5D), IL-4 (Fig. 5E) and IL-17 (Fig. 5F) were significantly upregulated in LPS treatment, which was in line with previous studies (36). Of note, after juglanin administration, these pro-inflammatory cytokines were highly downregulated compared to the LPS ones. In addition, the pro-inflammatory cytokines in lung 


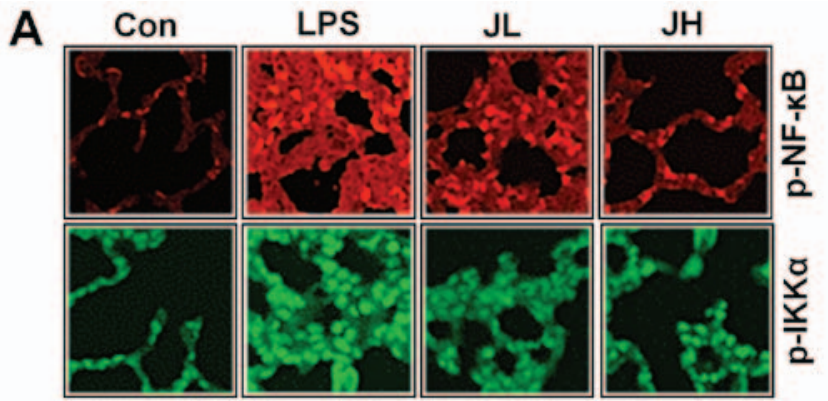

B

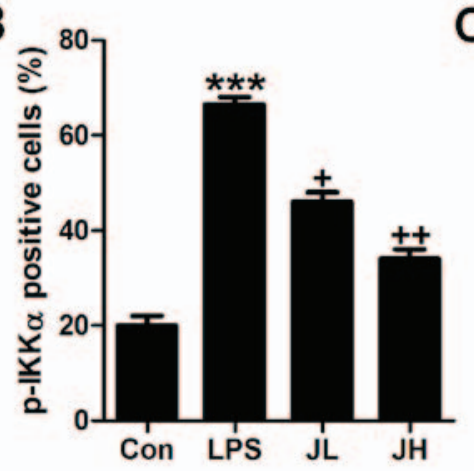

C

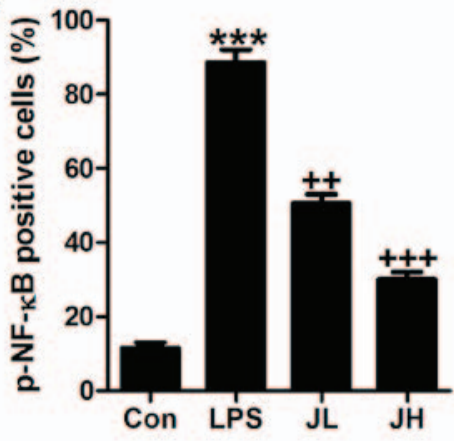

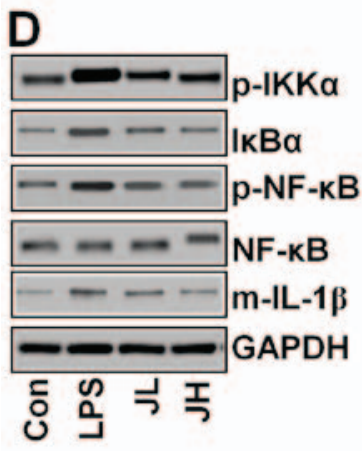

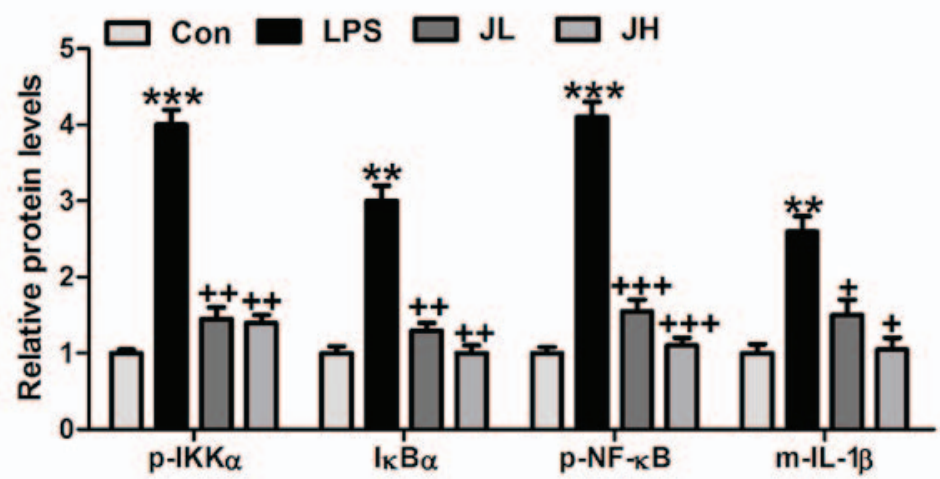

Figure 6. Nuclear factor- $\kappa \mathrm{B}(\mathrm{NF}-\kappa \mathrm{B})$ signaling pathway was involved in juglanin-ameliorated inflammation response in mice with acute lung injury induced by lipopolysaccharide (LPS). (A) Immunofluorescence was included to explore phosphorylated NF- $\kappa \mathrm{B}$ and IKK $\alpha$ expression levels. (B) The phosphorylated NF- $\kappa \mathrm{B}$ and (C) IKK $\alpha$ levels were quantified following immunofluorescence analysis. (D) Western blot analysis was conducted to explore IKK $\alpha / \mathrm{NF}-\kappa \mathrm{B}$ signaling pathway, including signals of IKK $\alpha$ phosphorylation, IкB $\alpha, \mathrm{NF}-\kappa \mathrm{B}$ phosphorylation as well as the mature IL-1 $\beta$, and the quantified levels are displayed in the right panel. The data are shown as mean \pm SEM $(n=10)$. ${ }^{*} \mathrm{p}<0.05$ and ${ }^{*} \mathrm{p}<0.001$ vs. the control (Con); ${ }^{+} \mathrm{p}<0.05,{ }^{++} \mathrm{p}<0.01$ and ${ }^{+++} \mathrm{p}<0.001 \mathrm{vs}$. LPS-induced mice (LPS).

tissue samples were also found to be upregulated with higher expression of TNF- $\alpha$ (Fig. 5G), IL-1 $\beta$ (Fig. 5H), IL-18 (Fig. 5I), IL-6 (Fig. 5J), IL-4 (Fig. 5K) and IL-17 (Fig. 5L), which were also reduced in juglanin treatment. The data above indicated that juglanin has a role in suppressing inflammation response in LPS-induced acute lung injury in mice.

$N F-\kappa B$ signaling pathwaywas involvedinjuglanin-ameliorated inflammation response in mice with acute lung injury induced by LPS. As mentioned above, inflammation response has been observed in LPS-induced mice with acute lung injury. Thus, here we attempted to explore how juglanin altered LPS-induced acute lung injury in mice. NF- $\mathrm{B}$ signaling pathway is a key to modulate pro-inflammatory cytokine releases (37). Thus, in our study, this classic pathway was also investigated to prove whether $\mathrm{NF}-\kappa \mathrm{B}$ was involved in our study. As shown in Fig. 6A, immunofluorescent analysis was carried out to explore how phosphorylated $\mathrm{NF}-\kappa \mathrm{B}$ and IKK $\alpha$ are changed in LPS-treated mice with or without juglanin treatment. The data indicated that $\mathrm{NF}-\kappa \mathrm{B}$ and IKK $\alpha$ phosphorylation levels were dramatically upregulated in LPS treatment, which were then significantly downregulated for juglanin treatment in a dosedependent manner (Fig. 6B and C). In addition, IgG-isotype control staining suggested that no positive signal was observed by immunofluorescent analysis. Furthermore, western blot analysis was used to prove that IKK $\alpha$ phosphorylated levels, I $\kappa \mathrm{B} \alpha$ expression, and $\mathrm{NF}-\kappa \mathrm{B}$ activity were found to be stimulated greatly by LPS treatment compared to the Con group, which was downregulated in the juglanin-treated groups, contributing to pro-inflammatory cytokine of IL-1 $\beta$ decrease (Fig. 6D). The data here indicated that juglanin could attenuate LPS-induced inflammation response through pro-inflammatory cytokine release via IKK $\alpha / \mathrm{NF}-\kappa \mathrm{B}$ signaling pathway suppression.

The effects of juglanin on the toxicity in vitro and in vivo. We evidenced in vivo that juglanin showed suppressive role in acute lung injury progression in LPS-treated mice. As further confirmation in vitro studies were carried out. The cell viability was estimated for juglanin treatment in BEAS-2B 

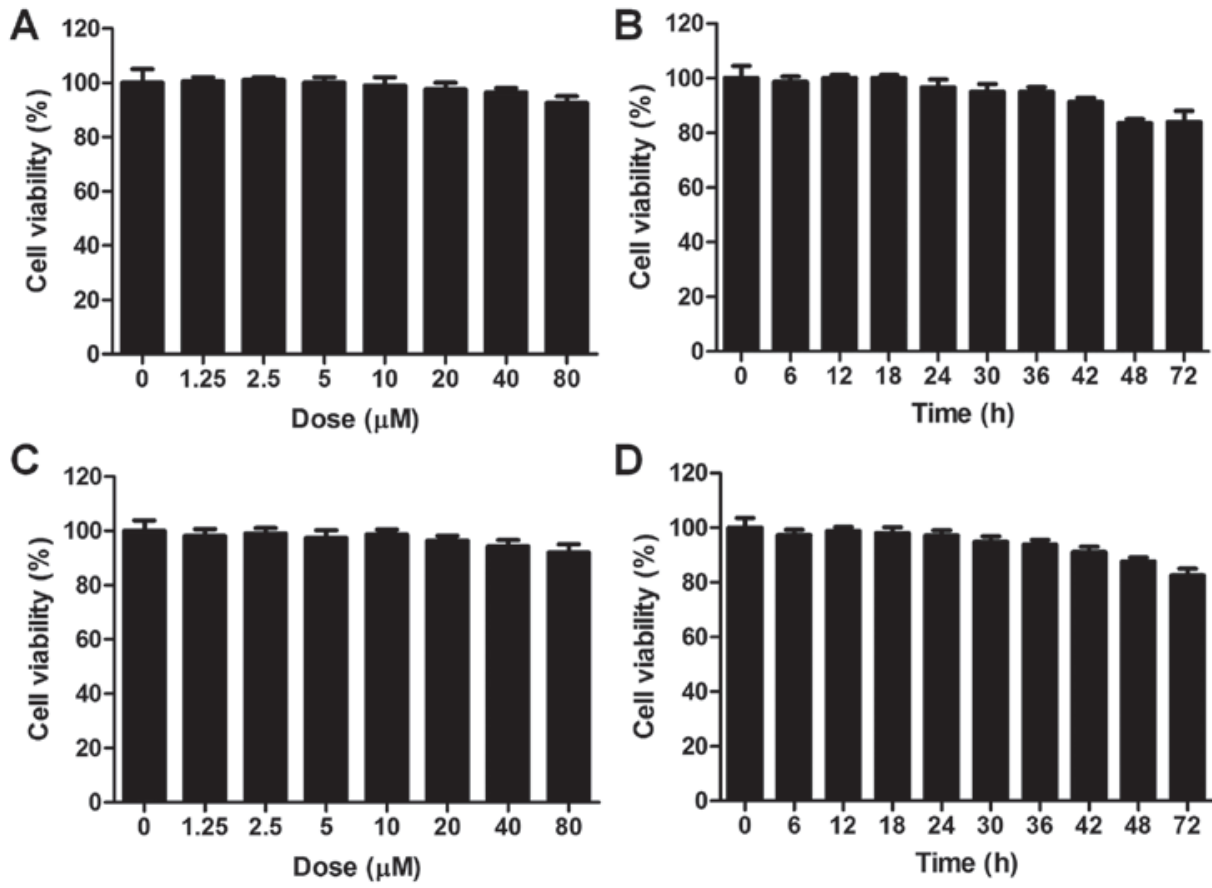

Figure 7. The effects of juglanin on the cell viability in vitro. (A) Cell counting kit-8 (CKK-8) assays were used to calculate normal lung cell BEAS-2B viability. The cells were treated with different concentrations $(0,1.25,2.5,5,10,20,40$ and $80 \mu \mathrm{M})$ of juglanin for $24 \mathrm{~h}$, followed by CCK- 8 analysis. (B) The BEAS-2B cells were treated with $80 \mu \mathrm{M}$ juglanin for different times as indicated. Then, the cell viability was measured. (C) The liver normal cells, L02, were treated with different concentrations of juglanin ranging from 0 to $80 \mu \mathrm{M}$ for $24 \mathrm{~h}$. Then, CCK- 8 analysis was conducted to calculate the cell viability. (D) The L02 cells were treated with $80 \mu \mathrm{M}$ juglanin for various times ( 0 to $72 \mathrm{~h}$ ). Then, the L02 cell viability was determined.

cells (Fig. 7A). The cells were treated with different concentrations of juglanin ranging from 0 to $80 \mu \mathrm{M}$ for $24 \mathrm{~h}$. The cells were collected for CCK-8 assays. No significant difference was observed after juglanin administration, even at the highest dose of juglanin. Also, $80 \mu \mathrm{M}$ juglanin was used to treat cells for different times as indicated, and no difference was shown (Fig. 7B). In order to further ensure that juglanin was non-toxic on cells, liver normal L02 cells were used. As shown in Fig. 7C, L02 cells were treated with juglanin $(0$, $1.25,2.5,5,10,20,40$ and $80 \mu \mathrm{M}$ ) for $24 \mathrm{~h}$. The cell viability was not changed between the groups. Also, after various times of treatment, no significant difference was observed among the groups with $80 \mu \mathrm{M}$ treatment (Fig. 7D). Further, in vivo, the experimental mice without LPS induction were administered with juglanin at different concentrations. After sacrifice, the liver, renal and spleen tissue specimens were isolated for $\mathrm{H} \& \mathrm{E}$ staining. As shown in Fig. 7E, no significant difference was observed among the Con and the Con with juglanin treatment groups, indicating that juglanin induced little toxicity in vivo. The data above indicated that juglanin shows no toxicity on lung cells or liver cells. Thus, 40 and $80 \mu \mathrm{M}$ juglalnin was used for the following studies in vitro.

Juglanin suppresses fibrosis development in lung cells in vitro. Fibrosis expression levels were further explored to prove that juglanin is useful for acute lung injury improvement by fibrosis inhibition. As shown in Fig. 8A and B, $\alpha$-SMA was highly upregulated in $100 \mathrm{ng} / \mathrm{ml}$ LPS treatment, whereas downregulated by juglanin administration, which was in agreement with the results above in vivo. Next, western blot analysis further indiated that $\alpha$-SMA, TGF- $\beta 1$, collagen type I and collagen type III were dramatically upregulated in LPS treatment. Of note, juglanin administration showed extremely suppressive role for these fibrosis markers compared to the LPS alone-treated group (Fig. 8C and D). The data above illustrate that juglanin ameliorated LPS-induced fibrosis development in lung cells in vitro.

Juglanin inhibits inflammation response in lung cells induced by LPS in vitro. In vivo studies, we evidenced that inflammation response was induced for LPS. Thus, here we attempted to determine if juglanin could improve acute lung injury from inhibiting inflammatory response in lung cells of BEAS-2B. First, immunofluorescent analysis was carried out to calculate phosphorylated NF- $\kappa$ B levels. As shown in Fig. 9A and B, high intensity of phospho-NF- $\mathrm{B}$ was observed in LPS-treated cells, while being downregulated in juglanin administration in a dose-dependent manner. Furthermore, western blot analysis indicated that phospho-IKK $\alpha, \mathrm{I} \kappa \mathrm{B} \alpha$ and phospho-NF- $\kappa \mathrm{B}$ were dramatically upregulated in LPS-treated cells. Juglanin treatment at different concentrations could downregulate expression of these factors. In agreement with this, pro-inflammatory cytokines of IL-1 $\beta$ was apparently accelerated for LPS induction, which was reduced greatly for juglanin (Fig. 9C and D). Here, this study indicated that juglanin in vivo showed inhibitory role in inflammation response induced by LPS in vitro to attenuate lung injury.

\section{Discussion}

Acute lung injury in children has been reported previously $(1,38)$. Currently, though treatments have been investigated and advanced, short-term morbidity as well as mortality still always occur in patients. Many patients are 
A
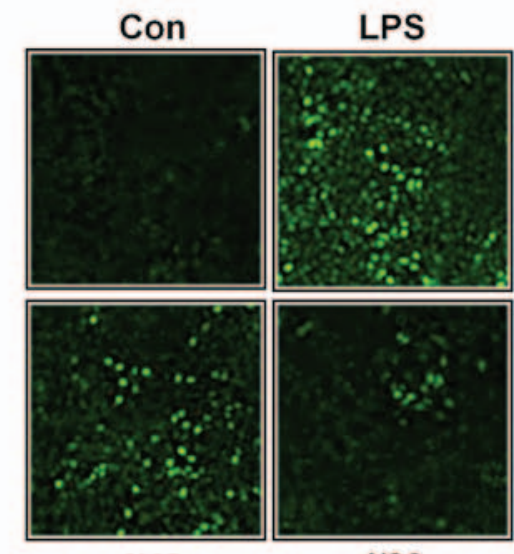

$\mathrm{J} / 40$

$\mathrm{J} / 80$

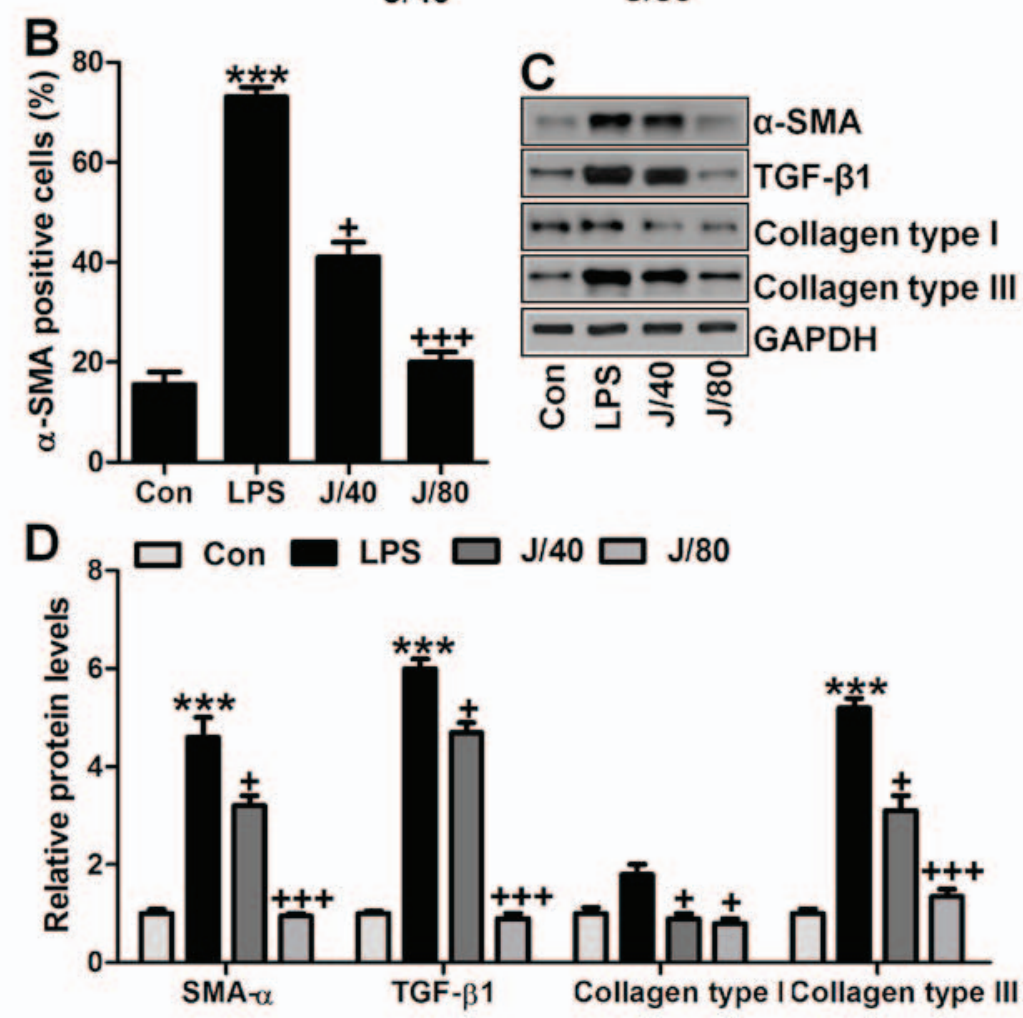

Figure 8. Juglanin suppressed fibrosis development in lung cells in vitro. (A) The lung cells of BEAS-2B were treated with 100 ng/ml lipopolysaccharide (LPS) for $24 \mathrm{~h}$, followed by 40 or $80 \mathrm{mM}$ juglanin administration for another $24 \mathrm{~h}$. Then, immunofluorescent analysis was used to calculate $\alpha$-smooth muscle-actin ( $\alpha$-SMA) positive cells. (B) The quantification of $\alpha$-SMA was assessed after immunofluorescence assays. (C) Western blot analysis was used to determine $\alpha$-SMA, transforming growth factor- $\beta 1$ (TGF- $\beta 1$ ), collagen type I and collagen type III expression levels in LPS-induced cells in the absence or presence of juglanin $(40$ or $80 \mu \mathrm{M})$. (D) The quantification of western blot analysis results is shown. The data are presented as mean \pm SEM (n=6). ${ }^{\mathrm{p}<0.05}$ and ${ }^{* *} \mathrm{p}<0.001$ vs. the control (Con); ${ }^{+} \mathrm{p}<0.05,{ }^{++} \mathrm{p}<0.01$ and ${ }^{+++} \mathrm{p}<0.001$ vs. LPS-induced mice (LPS).

unable to suppress lung injury due to severe tissue damage (39). Additionally, molecular mechanism still needs clarification on acute lung injury triggered by LPS, resembling the disease in human, leading to unusual metabolism $(40,41)$. Accumulating evidence has suggested that LPS treatment could result in lung dysfunction with serious injury (42). Juglanin is a natural compound extracted from the crude 'Polygonum aviculare', showing bioactivity against inflammation response, as well as cancer growth (43). Recently, the anti-inflammation and antioxidative activity of juglanin has been reported, suggesting that juglanin may possess effects on suppressing LPS-induced diseases (44). Therefore, in our present study, juglanin was investigated to clarify if it could be used as a therapeutic strategy in acute lung injury induced by LPS. This is the first time that juglanin was included in a study of acute lung injury from the aspects of fibrosis and inflammation regulation.

In our study, mice exposed to LPS were protected from acute lung injury due to juglanin administration. Mice exposed to LPS alone showed higher inflammation infiltration in BAL and $\operatorname{lgE}$ and $\lg \mathrm{A}$ both in serum and in BAL. Neutrophils and macrophages were the main inflammatory cells in acute lung injury. They infiltrated into the lung tissues, releasing enzymes phagocytizing the pathogen $(45,46)$. Moreover, these inflammatory cells were the fundamental source of inflammatory mediators in vivo (47). In LPS-induced inflammation, neutrophils and macrophages were activated. After activation, neutrophils and macrophages were recruited to the inflammation site (48). Lymphocytes have drawn increased 


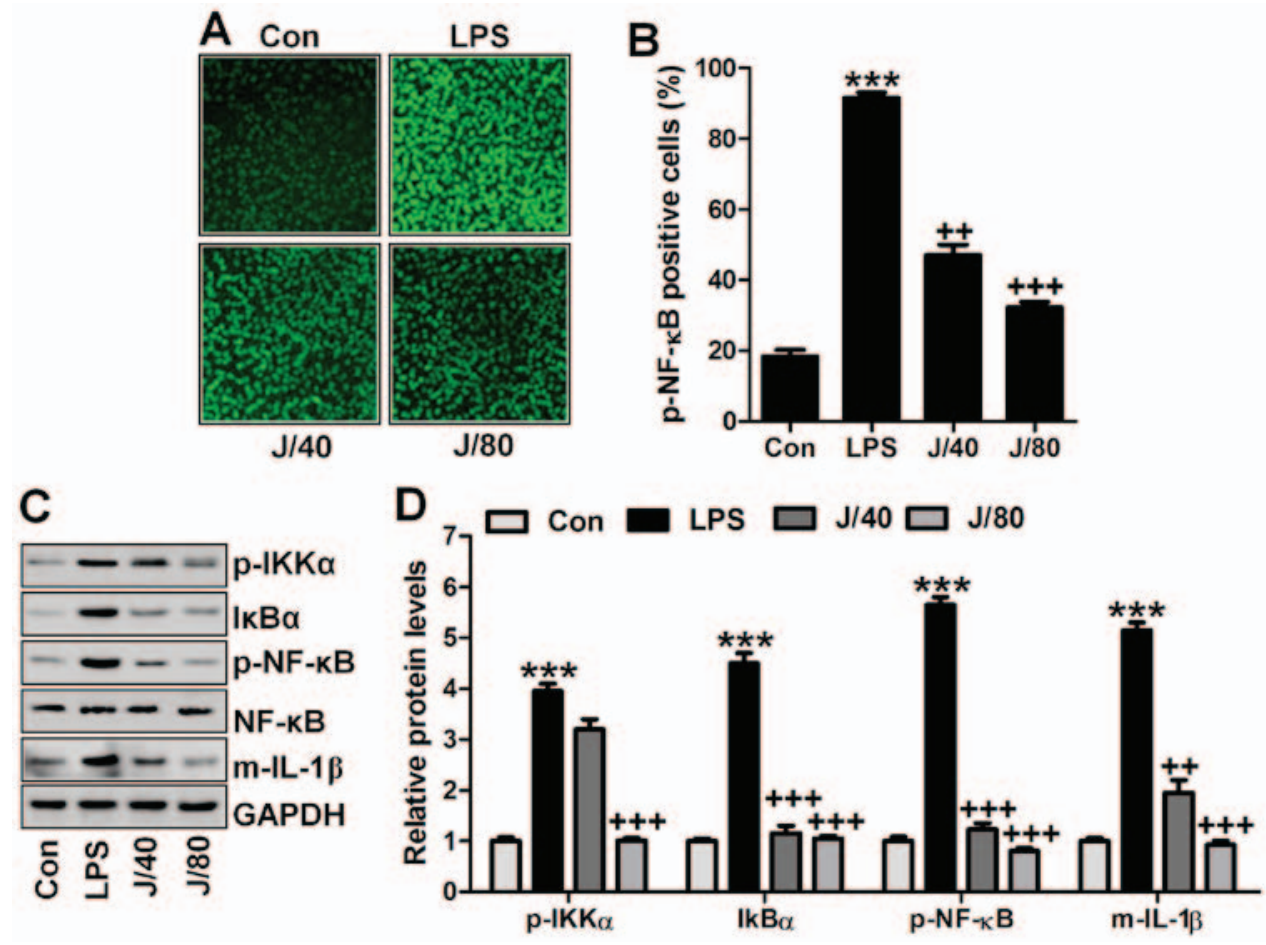

Figure 9. Juglanin inhibits inflammation response in lung cells induced by lipopolysaccharide (LPS) in vitro. The lung cells of BEAS-2B were treated with $100 \mathrm{ng} / \mathrm{ml}$ LPS for $24 \mathrm{~h}$, and then 40 or $80 \mu \mathrm{M}$ juglanin was administered to cells for another $24 \mathrm{~h}$. (A) The phosphorylated nuclear factor- $\kappa \mathrm{B}$ (NF- $\mathrm{kB}$ ) levels were assessed via immunofluorescent analysis. (B) The quantification of NF- $\kappa B$ phosphorylation is displayed. (C) IKK $\alpha$ phosphorylation, IкB $\alpha, N F-\kappa B$ phosphorylation, the mature interleukin-1 $\beta$ (IL-1 $\beta$ ) protein levels were measured by immunoblotting analysis. (D) The quantification of phosphorylated $\mathrm{IKK} \alpha / \mathrm{NF}-\mathrm{\kappa B}$, IкB $\alpha$ as well as IL-1 $\beta$ in mature formation. The data are represented as mean $\pm \mathrm{SEM}(\mathrm{n}=6)$. $\mathrm{p}<0.05$ and ${ }^{* *} \mathrm{p}<0.001 \mathrm{vs.}$ the control (Con); ${ }^{+} \mathrm{p}<0.05$, ${ }^{++} \mathrm{p}<0.01$ and ${ }^{+++} \mathrm{p}<0.001$ vs. LPS-induced mice (LPS).

attention, and there is accumulating evidence indicating that lymphocytes play important roles in the development and progression of acute lung injury $(49,50)$. It has been suggested that lymphocytes contribute to the progression of autoimmune and inflammatory diseases (51). Thus, these cells levels could be an indicator supporting the role of LPS on acute lung injury, and juglanin could reduce these cells to prevent inflammation response, revealing the antiinflammatory effect of juglanin on lung injury treatment. Previous studies reported that abundant abnormal collagen accumulation in lung tissue samples was observed after examination of patients with lung injury (52-54). In addition, the collagen type III accumulation may occur in lung disease of acute injury (55). In addition, $\alpha$-SMA expression is closely related to fibrosis accumulation (56). Further, LPS induction upregulated markers of fibrosis, such as $\alpha$-SMA, collagen type I and collagen type III, as well as TGF- $\beta 1$, which have been indicated as significant markers, inducing fibrosis development. TGF- $\beta 1$ is known to modulate various cellular responses (57). Significantly, TGF- $\beta 1$ is a key fibrotic cytokine, regulating organ fibrosis and dysfunction. During the progression of fibrosis, TGF- $\beta 1$ stimulates a number of fibrogenic genes, such as $\alpha$-SMA (58). In this study, we found that those markers were dramatically upregulated via western blot and RT-qPCR analysis, which was in line with previous studies (59). The results above indicated that LPS treatment, indeed, induced lung fibrosis development and progression in mice. Notably, juglanin has potential role in reducing fibrosis markers both in vitro and in vivo, improving fibrosis accumulation in the lung tissue samples of mice.
Inflammation is known to be involved in fibrosis development, accompanied with pro-inflammatory cytokine release, including IL-18, IL-6, IL-1 $\beta$ and TNF- $\alpha(60,61)$. NF- $\kappa$ B signaling pathway is of great importance in inflammation response through transfection activation (62). NF- $\mathrm{KB}$ phosphorylation could be activated following I $\mathrm{KB} \alpha$ activity improvement $(63,64)$. IKK $\alpha$, as an up-stream signal of I $\mathrm{KB} \alpha / \mathrm{NF}-\kappa \mathrm{B}$, was found to be upregulated

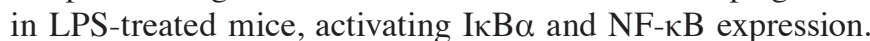
Pro-inflammatory cytokines of IL-6,IL-1 $\beta$ and TNF- $\alpha$ expression levels were also promoted subsequently, eventually contributing to inflammatory responses. Of note, juglanin exhibited antiinflammatory role in LPS-induced acute lung injury, which was in agreement with previous studies. Similarly, in vitro juglanin downregulated pro-inflammatory cytokine release, as well as $\mathrm{IKK} \alpha$, and I $\kappa \mathrm{B} \alpha / \mathrm{NF}-\kappa \mathrm{B}$ expression induced by LPS induction.

In conclusion, the data above suggested that LPS induced acute lung injury in mice with upregulation of $\alpha$-SMA, TGF- $\beta 1$ and collagen, which could be ameliorated by juglanin. Inflammatory response in mice and lung cells stimulated by LPS was also inhibited by juglanin through suppressing NF- $\mathrm{KB}$ signaling pathway. Significantly, our study suggested the possible role of juglanin in preventing acute lung injury by fibrosis formation and inflammation inhibition, which is of great value as useful assistant dietary supplements and for finding new and effective therapeutic strategy in acute lung injury for children in future.

\section{Acknowledgements}

The authors would like to thank the reviewers for their comments and help to promote this work. 


\section{Funding}

No funding was received.

\section{Availability of data and material}

The datasets used or analyzed during the current study are available from the corresponding author on reasonable request.

\section{Authors' contributions}

ZWD designed and performed the experiments. YFY wrote the manuscript. Both authors read and approved the final manuscript.

\section{Ethics approval and consent to participate}

This study was approved by the Ethics Committee on Animal Research at the Department of Pediatrics, Huai'an First People's Hospital, Nanjing Medical University, Nanjing, China.

\section{Consent for publication}

Not applicable.

\section{Competing interests}

The authors declare that they have no competing interests.

\section{References}

1. Saguil A and Fargo M: Acute respiratory distress syndrome: Diagnosis and management. Am Fam Physician 85: 352-358, 2012.

2. Cortés I, Peñuelas O and Esteban A: Acute respiratory distress syndrome: Evaluation and management. Minerva Anestesiol 78: 343-357, 2012

3. Brun-Buisson C, Minelli C, Bertolini G, Brazzi L, Pimentel J, Lewandowski K, Bion J, Romand JA, Villar J, Thorsteinsson A, et al; ALIVE Study Group: Epidemiology and outcome of acute lung injury in European intensive care units. Results from the ALIVE study. Intensive Care Med 30: 51-61, 2004.

4. Ware LB: Clinical year in review IV: Acute respiratory distress syndrome, radiology in the intensive care unit, nonpulmonary critical care, and pulmonary infections in the immunocompromised host. Proc Am Thorac Soc 5: 755-760, 2008.

5. Mofidi A, Bader A and Pavlica S: The use of erythropoietin and its derivatives to treat spinal cord injury. Mini Rev Med Chem 11: 763-770, 2011.

6. Matthay MA and Zemans RL: The acute respiratory distress syndrome: Pathogenesis and treatment. Annu Rev Pathol 6: 147-163, 2011.

7. Li B, Yang J, Huang Q, Zhang Y, Peng C, Zhang Y, He Y, Shi J, $\mathrm{Li} \mathrm{W}, \mathrm{Hu} \mathrm{J}$, et al: Biodistribution and pulmonary toxicity of intratracheally instilled graphene oxide in mice. NPG Asia Mater 5 : e44, 2013.

8. Spragg RG, Bernard GR, Checkley W, Curtis JR, Gajic O, Guyatt G, Hall J, Israel E, Jain M, Needham DM, et al: Beyond mortality: Future clinical research in acute lung injury. Am J Respir Crit Care Med 181: 1121-1127, 2010.

9. Rubenfeld GD, Caldwell E, Peabody E, Weaver J, Martin DP, Neff M, Stern EJ and Hudson LD: Incidence and outcomes of acute lung injury. N Engl J Med 353: 1685-1693, 2005.

10. Muñoz NM, Meliton AY, Meliton LN, Dudek SM and Leff AR Secretory group $\mathrm{V}$ phospholipase $\mathrm{A} 2$ regulates acute lung injury and neutrophilic inflammation caused by LPS in mice. Am J Physiol Lung Cell Mol Physiol 296: L879-L887, 2009.

11. Mei SH, McCarter SD, Deng Y, Parker CH, Liles WC and Stewart DJ: Prevention of LPS-induced acute lung injury in mice by mesenchymal stem cells overexpressing angiopoietin 1. PLoS Med 4: e269, 2007.
12. Yang HH, Hwangbo K, Zheng MS, Son JK, Kim HY, Baek SH, Choi HC, Park SY and Kim JR: Inhibitory effects of juglanin on cellular senescence in human dermal fibroblasts. J Nat Med 68: 473-480, 2014.

13. Huang XY, Duan QY, Liu JX and Di DL: Determination of a novel diarylheptanoid (Juglanin B) from green walnut husks (Juglans regia L.) in rat plasma by high-performance liquid chromatography. Biomed Chromatogr 24: 307-311, 2010.

14. Zhong J, Yang Y, Xiao Z, Chen J, Aisa HA and Zhang T: Separation and purification of three flavonoids from the petal of Rosa rugosa Thunb. by HSCCC. Asian J Tradit Med 4: 220-227, 2009.

15. Procházková D, Boušová I and Wilhelmová N: Antioxidant and prooxidant properties of flavonoids. Fitoterapia 82: 513-523, 2011.

16. Agati G, Azzarello E, Pollastri S and Tattini M: Flavonoids as antioxidants in plants: Location and functional significance. Plant Sci 196: 67-76, 2012.

17. Parhiz H, Roohbakhsh A, Soltani F, Rezaee R and Iranshahi M: Antioxidant and anti-inflammatory properties of the citrus flavonoids hesperidin and hesperetin: An updated review of their molecular mechanisms and experimental models. Phytother Res 29: 323-331, 2015.

18. Cho N, Choi JH, Yang H, Jeong EJ, Lee KY, Kim YC and Sung SH: Neuroprotective and anti-inflammatory effects of flavonoids isolated from Rhus verniciflua in neuronal HT22 and microglial BV2 cell lines. Food Chem Toxicol 50: 1940-1945, 2012.

19. Fu Y, Chen J, Li YJ, Zheng YF and Li P: Antioxidant and antiinflammatory activities of six flavonoids separated from licorice. Food Chem 141: 1063-1071, 2013.

20. Berlier G, Gastaldi L, Ugazio E, Miletto I, Iliade P and Sapino S: Stabilization of quercetin flavonoid in MCM-41 mesoporous silica: Positive effect of surface functionalization. J Colloid Interface Sci 393: 109-118, 2013.

21. Soromou LW, Chen N, Jiang L, Huo M, Wei M, Chu X, Millimouno FM, Feng H, Sidime Y and Deng X: Astragalin attenuates lipopolysaccharide-induced inflammatory responses by downregulating NF- $\kappa \mathrm{B}$ signaling pathway. Biochem Biophys Res Commun 419: 256-261, 2012.

22. Askari G, Ghiasvand R, Feizi A, Ghanadian SM and Karimian J: The effect of quercetin supplementation on selected markers of inflammation and oxidative stress. J Res Med Sci 17: 637-641, 2012.

23. Bakhshaeshi M, Khaki A, Fathiazad F, Khaki AA and Ghadamkheir E: Anti-oxidative role of quercetin derived from Allium cepa on aldehyde oxidase (OX-LDL) and hepatocytes apoptosis in streptozotocin-induced diabetic rat. Asian Pac J Trop Biomed 2: 528-531, 2012.

24. Lee CC, Shen SR, Lai YJ and Wu SC: Rutin and quercetin, bioactive compounds from tartary buckwheat, prevent liver inflammatory injury. Food Funct 4: 794-802, 2013.

25. Chae HS, Kim YM, Lee EJ, Song HH, Oh SR, Choi YH and Chin YW: Corilagin with inhibitory activity against NO production from Euphorbia supina. Nat Prod Sci 20: 126-129, 2014.

26. Zhou GY, Yi YX, Jin LX, Lin W, Fang PP, Lin XZ, Zheng Y and Pan CW: The protective effect of juglanin on fructose-induced hepatitis by inhibiting inflammation and apoptosis through TLR4 and JAK2/STAT3 signaling pathways in fructose-fed rats. Biomed Pharmacother 81: 318-328, 2016.

27. Li C, Liu JX, Zhao L, Di DL, Meng M and Jiang SX: Capillary zone electrophoresis for separation and analysis of four diarylheptanoids and an $\alpha$-tetralone derivative in the green walnut husks (Juglans regia L.). J Pharm Biomed Anal 48: 749-753. 2008.

28. El-Salhy M, Lomholt-Beck B and Gundersen D: The prevalence of celiac disease in patients with irritable bowel syndrome. Mol Med Rep 4: 403-405, 2011.

29. Jensen EC: Quantitative analysis of histological staining and fluorescence using ImageJ. Anat Rec (Hoboken) 296: 378-381, 2013.

30. Kim HA, Park JH, Lee S, Choi JS, Rhim T and Lee M: Combined delivery of dexamethasone and plasmid DNA in an animal model of LPS-induced acute lung injury. J Control Release 156: 60-69, 2011.

31. Hague AS: Allergic bronchopulmonary aspergillosis. Pakistan J Chest Med 11: 19-26, 2015.

32. Martin TR and Matute-Bello G: Experimental models and emerging hypotheses for acute lung injury. Crit Care Clin 27: 735-752, 2011. 
33. Reiss LK, Uhlig U and Uhlig S: Models and mechanisms of acute lung injury caused by direct insults. Eur J Cell Biol 91: 590-601, 2012.

34. Su X, Bai C, Hong Q, Zhu D, He L, Wu J, Ding F, Fang X and Matthay MA: Effect of continuous hemofiltration on hemodynamics, lung inflammation and pulmonary edema in a canine model of acute lung injury. Intensive Care Med 29: 2034-2042, 2003.

35. Li B, Dong C, Wang G, Zheng H, Wang X and Bai C: Pulmonary epithelial CCR3 promotes LPS-induced lung inflammation by mediating release of IL-8. J Cell Physiol 226: 2398-2405, 2011.

36. Thorley AJ, Ford PA, Giembycz MA, Goldstraw P, Young A and Tetley TD: Differential regulation of cytokine release and leukocyte migration by lipopolysaccharide-stimulated primary human lung alveolar type II epithelial cells and macrophages. J Immunol 178: 463-473, 2007.

37. Wong ET and Tergaonkar V: Roles of NF-kappaB in health and disease: Mechanisms and therapeutic potential. Clin Sci (Lond) 116: 451-465, 2009.

38. Bhatia M, Zemans RL and Jeyaseelan S: Role of chemokines in the pathogenesis of acute lung injury. Am J Respir Cell Mol Biol 46: 566-572, 2012.

39. Matthay MA, Ware LB and Zimmerman GA: The acute respiratory distress syndrome. J Clin Invest 122: 2731-2740, 2012

40. Lee JP, Li YC, Chen HY, Lin RH, Huang SS, Chen HL, Kuan PC, Liao MF, Chen CJ and Kuan YH: Protective effects of luteolin against lipopolysaccharide-induced acute lung injury involves inhibition of MEK/ERK and PI3K/Akt pathways in neutrophils. Acta Pharmacol Sin 31: 831-838, 2010.

41. Kabir K, Gelinas JP, Chen M, Chen D, Zhang D, Luo X, Yang JH, Carter D and Rabinovici R: Characterization of a murine mode of endotoxin-induced acute lung injury. Shock 17: 300-303, 2002

42. Rojas M, Woods CR, Mora AL, Xu J and Brigham KL: Endotoxin-induced lung injury in mice: Structural, functional, and biochemical responses. Am J Physiol Lung Cell Mol Physiol 288: L333-L341, 2005.

43. Chen G, Pi XM and Yu CY: A new naphthalenone isolated from the green walnut husks of Juglans mandshurica Maxim. Nat Prod Res 29: 174-179, 2015.

44. Yoo G, Park SJ, Lee TH, Yang H, Baek YS, Kim N, Kim YJ and Kim SH: Flavonoids isolated from Lespedeza cuneata G. Don and their inhibitory effects on nitric oxide production in lipopolysaccharide-stimulated BV-2 microglia cells. Pharmacogn Mag 11: 651-656, 2015.

45. Zhu YG, Feng XM, Abbott J, Fang XH, Hao Q, Monsel A, Qu JM, Matthay MA and Lee JW: Human mesenchymal stem cell microvesicles for treatment of Escherichia coli endotoxininduced acute lung injury in mice. Stem Cells 32: 116-125, 2014

46. Bhatia M, Zemans RL and Jeyaseelan S: Role of chemokines in the pathogenesis of acute lung injury. Am J Respir Cell Mol Biol 46: 566-572, 2012.

47. Kovarova M, Hesker PR, Jania L, Nguyen M, Snouwaert JN, Xiang Z, Lommatzsch SE, Huang MT, Ting JP and Koller BH: NLRP1-dependent pyroptosis leads to acute lung injury and morbidity in mice. J Immunol 189: 2006-2016, 2012.

48. Zhu T, Wang DX, Zhang W, Liao XQ, Guan X, Bo H, Sun JY, Huang NW, He J, Zhang YK, et al: Andrographolide protects against LPS-induced acute lung injury by inactivation of NF- $\mathrm{NB}$ PLoS One 8: e56407, 2013.

49. Ci X, Chu X, Wei M, Yang X, Cai Q and Deng X: Different effects of farrerol on an OVA-induced allergic asthma and LPS-induced acute lung injury. PLoS One 7: e34634, 2012.

50. Xiao M, Zhu T, Zhang W, Wang T, Shen YC, Wan QF and Wen FQ: Emodin ameliorates LPS-induced acute lung injury, involving the inactivation of NF- $\mathrm{KB}$ in mice. Int $\mathrm{J}$ Mol Sci 15 : 19355-19368, 2014.
51. Garibaldi BT, D'Alessio FR, Mock JR, Files DC, Chau E, Eto Y, Drummond MB, Aggarwal NR, Sidhaye V and King LS: Regulatory $\mathrm{T}$ cells reduce acute lung injury fibroproliferation by decreasing fibrocyte recruitment. Am J Respir Cell Mol Biol 48: 35-43, 2013.

52. Tsukada S, Westwick JK, Ikejima K, Sato N and Rippe RA: SMAD and p38 MAPK signaling pathways independently regulate $\alpha 1$ (I) collagen gene expression in unstimulated and transforming growth factor- $\beta$-stimulated hepatic stellate cells. J Biol Chem 280: 10055-10064, 2005.

53. Dempsey OJ and Miller D: Idiopathic pulmonary fibrosis. BMJ 347: f6579, 2013.

54. Mahendran S and Sethi T: Treatments in idiopathic pulmonary fibrosis: Time for a more targeted approach? QJM 105: 929-934, 2012.

55. Ghaffari AR, Noshad H, Ostadi A and Hasanzadeh N: Effect of pulse therapy with glucocorticoid and cyclophosphamide in lung fibrosis due to paraquat poisoning in rats. Saudi Med J 32: 249-253, 2011.

56. Ghazi-Khansari M, Mohammadi-Karakani A, Sotoudeh M, Mokhtary P, Pour-Esmaeil E and Maghsoud S: Antifibrotic effect of captopril and enalapril on paraquat-induced lung fibrosis in rats. J Appl Toxicol 27: 342-349, 2007

57. Chen CM, Chou HC, Hsu HH and Wang LF: Transforming growth factor- $\beta 1$ upregulation is independent of angiotensin in paraquat-induced lung fibrosis. Toxicology 216: 181-187, 2005.

58. Son JY, Kim SY, Cho SH, Shim HS, Jung JY, Kim EY, Lim JE, Park BH, Kang YA, Kim YS, et al: TGF- $\beta 1$ T869C polymorphism may affect susceptibility to idiopathic pulmonary fibrosis and disease severity. Lung 191: 199-205, 2013.

59. Madhyastha R, Madhyastha H, Pengjam Y, Nakajima Y, Omura S and Maruyama M: NFkappaB activation is essential for miR-21 induction by TGF $\beta 1$ in high glucose conditions. Biochem Biophys Res Commun 451: 615-621, 2014

60. Bastard JP, Jardel C, Bruckert E, Blondy P, Capeau J, Laville M, Vidal $\mathrm{H}$ and Hainque B: Elevated levels of interleukin 6 are reduced in serum and subcutaneous adipose tissue of obese women after weight loss. J Clin Endocrinol Metab 85: 3338-3342, 2000.

61. Lu CN, Yuan ZG, Zhang XL, Yan R, Zhao YQ, Liao M and Chen JX: Saikosaponin a and its epimer saikosaponin d exhibit anti-inflammatory activity by suppressing activation of NF- $\kappa B$ signaling pathway. Int Immunopharmacol 14: 121-126, 2012.

62. Nieto-Vazquez I, Fernández-Veledo S, Krämer DK, Vila-Bedmar R, Garcia-Guerra L and Lorenzo M: Insulin resistance associated to obesity: The link TNF-alpha. Arch Physiol Biochem 114: 183-194, 2008.

63. Zhang HH, Halbleib M, Ahmad F, Manganiello VC and Greenberg AS: Tumor necrosis factor-alpha stimulates lipolysis in differentiated human adipocytes through activation of extracellular signal-related kinase and elevation of intracellular cAMP. Diabetes 51: 2929-2935, 2002.

64. Wang SL, Li Y, Wen Y, Chen YF, Na LX, Li ST and Sun CH: Curcumin, a potential inhibitor of upregulation of TNF-alpha and IL-6 induced by palmitate in 3T3-L1 adipocytes through NF-kappaB and JNK pathway. Biomed Environ Sci 22: 32-39, 2009.

This work is licensed under a Creative Commons Attribution-NonCommercial-NoDerivatives 4.0 International (CC BY-NC-ND 4.0) License. 